\title{
ECOSYSTEM ENGINEERING OF HARVESTER ANTS: EFFECTS ON VEGETATION IN A SAGEBRUSH-STEPPE ECOSYSTEM
}

\author{
Elyce N. Gosselin ${ }^{1}$, Joseph D. Holbrook ${ }^{1,3}$, Katey Huggler ${ }^{1}$, Emily Brown ${ }^{1}$, \\ Kerri T. Vierling ${ }^{1}$, Robert S. Arkle ${ }^{2}$, and David S. Pilliod ${ }^{2}$
}

\begin{abstract}
Harvester ants are influential in many ecosystems because they distribute and consume seeds, remove vegetation, and redistribute soil particles and nutrients. Understanding the interaction between harvester ants and plant communities is important for management and restoration efforts, particularly in systems altered by fire and invasive species such as the sagebrush-steppe. Our objective was to evaluate how vegetation cover changed as a function of distance from Owyhee harvester ant (Pogonomyrmex salinus) nests within a sagebrush-steppe ecosystem. We sampled 105 harvester ant nests within southern Idaho, USA, that occurred in different habitats: annual grassland, perennial grassland, and native shrubland. The influence of Owyhee harvester ants on vegetation was larger at the edge of ant nests, but the relationship was inconsistent among plant species. Percent cover was positively associated with distance from harvester ant nests for plant species that were considered undesirable food sources and were densely distributed. However, percent cover was negatively associated with distance-from-nests for patchily distributed and desirable plant species. For some plant species, there was no change in cover associated with distance-from-nests. Total vegetation cover was associated with distance-from-nests in the shrubland habitat but not in the 2 grasslands. The dominant plant species in the shrubland habitat was a densely distributed shrub (winterfat, Krascheninnikovia lanata) that was defoliated by harvester ants. Our results suggest that Owyhee harvester ants increase spatial heterogeneity in plant communities through plant clearing, but the direction and magnitude of effect will likely be contingent on the dominant vegetation groups. This information may inform future management and plant restoration efforts in sagebrush-steppe by directly considering the islands of influence associated with harvester ant engineering.
\end{abstract}

RESUMEN.-Las hormigas cosechadoras tienen influencia en muchos ecosistemas, ya que distribuyen y consumen semillas, eliminan vegetación, y redistribuyen partículas del suelo y nutrientes. Es importante entender las interacciones entre las hormigas cosechadoras y las comunidades vegetales para el esfuerzo de manejo y la restauración, en particular en los sistemas alterados por el fuego y especies invasoras, como la estepa de artemisa. Nuestro objetivo se centró en evaluar cómo ha cambiado la cobertura vegetal en función a la distancia de los hormigueros de Pogonomyrmex salinus en un ecosistema de estepa de artemisas. Muestreamos 105 hormigueros de hormigas cosechadoras en el sur de Idaho, Estados Unidos. Las hormigas se distribuyen en diferentes hábitats: pastizales anuales, pastos perennes y matorrales nativos. La influencia de las hormigas cosechadoras de Owyhee en la vegetación fue mayor en el borde de los hormigueros, pero la relación fue inconsistente entre las especies de plantas. El porcentaje de cobertura se asoció positivamente con la distancia a los hormigueros para las especies de plantas que se consideraban fuentes de alimento indeseable y que estaban distribuidas densamente. Sin embargo, el porcentaje de cobertura se asoció negativamente con la distancia a los hormigueros en especies de plantas deseables y distribuidas en parches. Para algunas especies de plantas, no hubo cambio en la cobertura vegetal asociado con la distancia a los hormigueros. La cobertura vegetal total se asoció con la distancia a los hormigueros en el matorral, pero no en los pastizales. Las especies vegetales dominantes en el hábitat de matorral constituían arbustos densamente distribuidos (Krascheninnikovia lanata) que fueron defoliados por hormigas cosechadoras. Nuestros resultados sugieren que las hormigas cosechadoras Owyhee aumentan la heterogeneidad espacial en las comunidades de plantas a través de la limpieza de plantas, pero la dirección y la magnitud de su efecto es probable que sea contingente a los grupos de vegetación dominante. Esta información puede resultar útil para futuras tareas de manejo y restauración de plantas artemisas en la estepa de artemisas al considerar directamente las islas de influencia asociadas a la ingeniería de la hormigas cosechadoras.

In many ecosystems, burrowing animals act as ecosystem engineers, physically modifying habitat and increasing spatial heterogeneity (Whitford and Kay 1999, Eldridge and Whitford 2009, Davidson et al. 2012, Fleming et al. 2014). An ecosystem engineer is an organism that directly or indirectly alters its surroundings by modifying biotic or abiotic materials, and thus alters resource availability for other species (Jones et al. 1994, 1997, 2010). Burrowing animals aerate soils and redistribute soil particles and nutrients by creating underground

\footnotetext{
${ }^{1}$ Department of Fish and Wildlife Sciences, University of Idaho, Moscow, ID 83844-1136.

${ }^{2}$ U.S. Geological Survey, Forest and Rangeland Ecosystem Science Center, Boise, ID 83706

${ }^{3}$ Corresponding author. E-mail: jholbrook03@gmail.com
} 
tunnel systems (Jones et al. 1994, Whitford and DiMarco 1995, Eldridge and Whitford 2009). These activities create patches of disturbed ground that influence vegetation growth and contribute to spatial heterogeneity in plant communities (Whicker and Detling 1988, Davidson et al. 2012).

Harvester ants (i.e., Pogonomyrmex and Messor spp.) are burrowing animals that influence vegetation through ecosystem engineering and trophic pathways. Harvester ants alter soil properties through burrowing, which increases soil nutrients and water absorption on and near nests (Mandel and Sorenson 1982, Whitford 1988, Wagner et al. 1997, Wilby et al. 2001, Wagner and Jones 2006, Brown et al. 2012). Consequently, vegetation abundance generally increases near nests (e.g., Golley and Gentry 1964, Whitford 1988, Brown et al. 2012). Additionally, harvester ants collect, consume, and store seeds underground, and as a result, move seeds throughout the landscape (MacMahon et al. 2000). Finally, harvester ants selectively defoliate or maintain vegetation on and around nests, which influences the plant cover and species composition of some landscapes in fairly large proportions (Carlson and Whitford 1991, Holbrook et al. 2015). Thus, harvester ants may have important influences on desirable native vegetation, as well as restoration efforts within sagebrush-steppe ecosystems, which are considered among the most imperiled in North America (Noss et al. 1995, Noss and Peters 1995). Sagebrushsteppe has declined by $50 \%$ in the last 200 years (Knick et al. 2003, Schroeder et al. 2004) as a result of exotic grass invasion, conifer encroachment, human use, and altered fire regimes (Davies et al. 2011). Vast areas of burned or degraded sagebrush shrublands are being restored annually (mainly through largescale seed sowing) in an attempt to reverse widespread habitat loss for sagebrush-dependent species, like Greater Sage-Grouse (Centrocercus urophasianus; Arkle et al. 2014). Harvester ants have the potential to influence restoration outcomes because of their widespread distribution in arid shrublands of North America and their removal of seeds (e.g., DeFalco et al. 2009, Ostoja et al. 2009, Suazo et al. 2013) and plant material (e.g., Bucy and Breed 2006, DeFalco et al. 2009).

The Owyhee harvester ant is a semiclaustral, haplometrotic harvester ant (Anderson and Keyel 2006) found throughout southwestern Canada and the western United States (Rust 1988). Like the nests of other members of the genus Pogonomyrmex (MacMahon et al. 2000), nests of Owyhee harvester ants are surrounded by a disk that is generally cleared of all vegetation. Density of Owyhee harvester ants can range up to 164 nests per hectare (Blom et al. 1991), and foragers from closely spaced colonies forage within nonoverlapping boundaries to avoid encounters with neighboring colonies (Howell 2015).

Our research objective was to assess the influence of Owyhee harvester ants (hereafter, harvester ants) on vegetation at the nest scale (i.e., 0-3 m) within the sagebrush-steppe. We selected 3 habitats to include in our sample, which consisted of (1) an annual grassland site that was dominated by a densely distributed invasive grass, (2) a perennial grassland site that was dominated by patchy native and introduced bunchgrasses, and (3) a shrubland site that was dominated by a comparatively dense native shrub. Harvester ants remove plants near their nests to increase soil moisture and sun exposure (Wight and Nichols 1966, Bucy and Breed 2006), which are important for colony survival (Cole 1932). However, in some cases, harvester ants may maintain plants on or near their nests that produce desirable food resources (e.g., Nowak et al. 1990). Harvester ants also indirectly influence plant species abundance and composition on and near their nest mounds through physical modification of soil and nutrients (Carlson and Whitford 1991, Lei 1999). Thus, we hypothesized that as vegetation density increased, we would observe a larger reduction in vegetation cover at distances closer to nests because of plant removal or defoliation, but we expected this relationship to change based on the functional role of the plant to ants (e.g., seed preferences). Overall, this work contributes to the understanding of animal-mediated processes influencing spatial heterogeneity within plant communities in sagebrush-steppe.

\section{Study AREA}

Our study was conducted within the Morley Nelson Snake River Birds of Prey National Conservation Area (BOP), a $1962-\mathrm{km}^{2}$ region in southwestern Idaho (lat 43.283, long - 116.200). The BOP is located in an arid $(110-350 \mathrm{~mm}$ 
annual precipitation) sagebrush-steppe habitat and is managed by the U.S. Bureau of Land Management under a multiple-use framework. In June and July 2014, we sampled harvester ant nests within three 1-ha sites characterized by annual grassland, perennial grassland, and shrubland. Plant senescence generally occurred prior to our sampling period; thus, our results were not confounded by differences in seasonal growth strategies of plants. The annual grassland had coarse-silt soil and was burned in 1996 but was not seeded postfire. The dominant plant species was exotic Bromus tectorum and native Sandberg bluegrass (Poa secunda). The perennial grassland was also on coarse-silt soil and was burned in 1996 and seeded in 1997. This site was dominated by P. secunda and exotic Russian wildrye (Psathyrostachys juncea). The shrubland had a coarseloam soil and had not burned in the last 30 years. The dominant plant species was native winterfat (Krascheninnikovia lanata) and $P$. secunda.

\section{METHODS}

At each of the sites, we censused and mapped all active harvester ant nests, which amounted to $\geq 30$ nests per site. To measure the nest area, we recorded 2 measurements of the disk diameter at the nest; one in a north-south orientation and one in an eastwest orientation. We measured distances between the nest edges, which we defined by the widest area of bare ground where no vegetation was growing. We averaged the 2 diameter measurements and calculated the average nest area by applying the equation for area of a circle $\left(A=0.25 \pi d^{2}\right.$, where $d=$ average nest diameter). Additionally, we calculated the total area covered by nests within a 1-ha area by summing nest areas.

To evaluate how plant species and total vegetation cover changed as a function of distance from harvester ant nests, we characterized the vegetation at 3 distances from each nest in each of the 4 cardinal directions. We placed a $0.25 \times 0.5-\mathrm{m}$ quadrat at $0,1.5$, and $3 \mathrm{~m}$ from the nest edge for a total of 12 quadrats per nest (3 distances $\times 4$ directions). We limited our sampling extent to $3 \mathrm{~m}$ from harvester ant nests because-although the mean foraging distance of $P$. salinus was found to be $8.0 \mathrm{~m}$ in a sagebrush-greasewood community (Jorgensen and Porter 1982)—we wanted to capture the major area of influence associated with harvester ants, and foraging decreases exponentially as distance from ant nests increases (Crist and MacMahon 1991). At each quadrat surrounding the nest, we collected nadir $\left(90^{\circ}\right.$ angle) photographs using a Canon Powershot SX20 IS (12.1-megapixel resolution) from a distance of $2 \mathrm{~m}$ from the ground using a polyvinyl chloride (PVC) monopod (see Pilliod and Arkle 2013).

We used SamplePoint 1.56 software (Booth et al. 2006) to measure the percent cover of each species, as well as total vegetation cover, within photos. We cropped each photo to the area inside of the quadrat and generated 64 computer-selected grid points. We manually categorized each point as a plant species, unidentifiable grasses, or extraneous material (e.g., soil, scat, shadows, downed woody debris). For photos from the shrubland habitat, we categorized $K$. lanata either as defoliated (i.e., no leaves and inflorescences) or foliated to assess how foliage state changed as a function of distance from nest. We then used SamplePoint to generate cover estimates for each species category within each photo. For each nest, we averaged these cover estimates across the 4 photos within each distance class. Thus, 256 individual points (i.e., subsampling locations) contribute to cover estimates generated for each species at a given distance from each nest, with a total of 80,640 points being classified.

For statistical evaluation, we treated each harvester ant nest as an independent sample and summarized the data based on dominant vegetation (i.e., habitat). We calculated 95\% confidence intervals to assess statistical differences in species and total vegetation cover across our gradient of distance-from-nest. Only plant species identified in $\geq 10 \%$ of photos in at least one distance class $(0 \mathrm{~m}, 1.5 \mathrm{~m}, 3 \mathrm{~m})$ were included in species-level analyses. To evaluate changes in total vegetation cover (i.e., cover by any species), we used the average percent cover for all detected plants, including unidentified grasses. Finally, we assessed differences in cover estimates of defoliated and foliated $K$. lanata within each distance class in the shrubland habitat using $95 \%$ confidence intervals. All analyses were performed in Program R (version 3.1.1) using the Rmisc package (R Core Team 2014). 

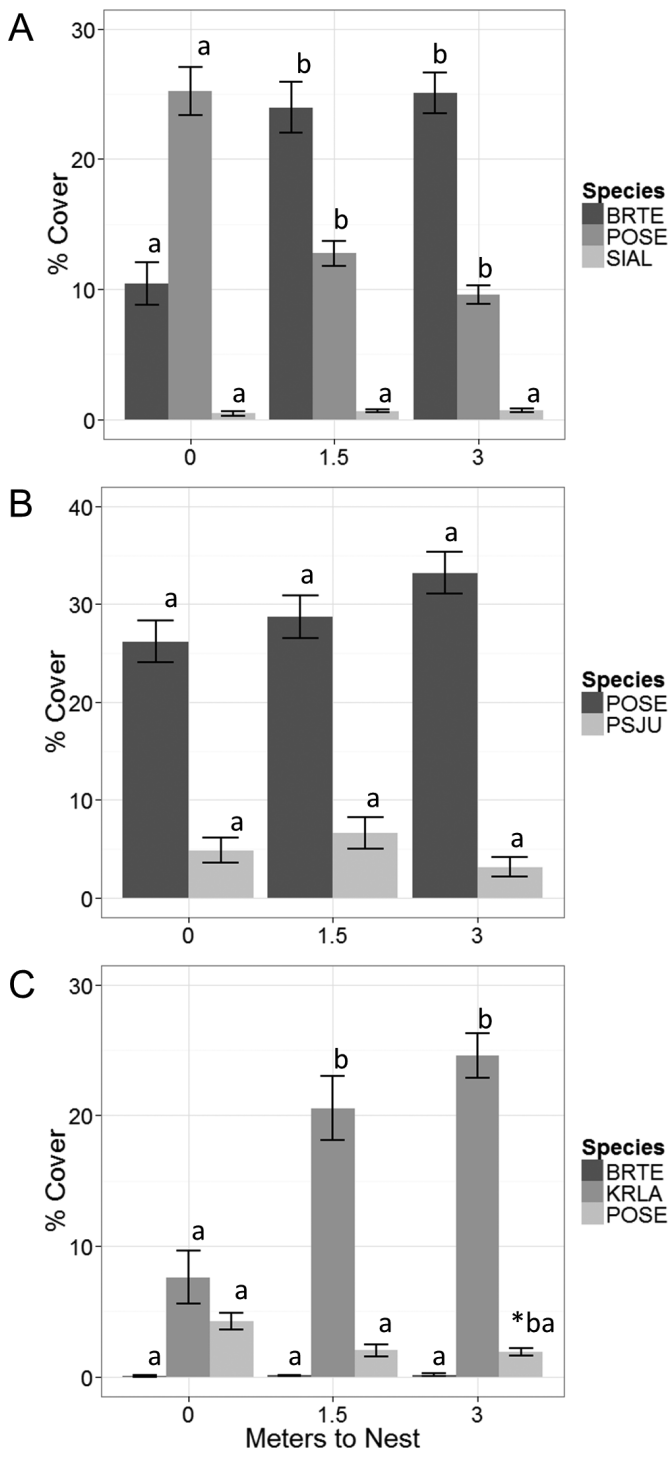

Fig. 1. Mean percent cover $( \pm 1 \mathrm{SE})$ of plant species as a function of distance from Owyhee harvester ant (Pogonomyrmex salinus) nests: A, annual grassland; $\mathbf{B}$, perennial grassland; C, shrubland. Plant codes: BRTE $=$ Bromus tectorum, $\mathrm{POSE}=$ Poa secunda, $\mathrm{SIAL}=$ Sisymbrium altissimum, $\mathrm{PSJU}=$ Psathrostachys juncea, $\mathrm{KRLA}=$ Krascheninnikovia lanata. Different letters denote significant differences in cover across distance classes based on $95 \%$ confidence intervals. Note different $y$-axis scale in panel $\mathrm{B}$, and the asterisk in panel $\mathrm{C}$ indicates a difference in POSE cover between $0 \mathrm{~m}$ and $3 \mathrm{~m}(\alpha=0.10)$.

\section{RESULTS}

At the annual grassland, perennial grassland, and shrubland habitat, the densities of active harvester ant mounds were 39,36 , and 30 nests $\cdot \mathrm{ha}^{-1}$, and the average nest areas were $0.21,0.30$, and $0.49 \mathrm{~m}^{2}$, respectively. Harvester ant nests comprised a total of 9, 12, and $16 \mathrm{~m}^{2}$ at the annual grassland, perennial grassland, and shrubland, respectively.

Cover of several plant species differed significantly as a function of distance from harvester ant nests. In the annual grassland, $B$. tectorum cover increased and $P$. secunda cover decreased significantly from the edge of the nest to 1.5 and $3 \mathrm{~m}$ from the edge (Fig. 1A). There were no significant changes in cover of tall tumblemustard (Sisymbrium altissimum) across distances. In the perennial grassland, there were no significant changes in $P$. secunda or $P$. juncea cover with distance-fromnest (Fig. 1B). In the shrubland, we observed a statistically significant decrease between $P$. secunda at the nest edge and $3 \mathrm{~m}(\alpha=0.10$; $\mathrm{b}$ with asterisk in Fig. 1C). We documented a significant increase in $K$. lanata from the edge to 1.5 and $3 \mathrm{~m}$, but no significant change in B. tectorum cover across distances (Fig. 1C). Lastly, we observed significantly more defoliated than foliated $K$. lanata cover, but only at the 0 -m distance class (Fig. 2).

In contrast to our species-specific results, total vegetation cover only changed as a function of distance-from-nest in the shrubland, where the nest edge has less total cover than the 1.5-m and 3-m distances (Fig. 3). Although there were significant changes in $P$. secunda and B. tectorum cover in the annual grassland, there was no significant change in total vegetation cover. Similarly, we observed no significant change in vegetation cover in the perennial grassland.

\section{Discussion}

Our findings support the notion that Owyhee harvester ants act as ecosystem engineers within sagebrush-steppe habitats and contribute to spatial heterogeneity in plant communities through small-scale changes magnified by the abundance of nests. We discovered that nest density of harvester ants ranged from 30 to 39 nests $\cdot \mathrm{ha}^{-1}$, with as much as $16 \mathrm{~m}^{2}$ of land denuded per hectare. These values are lower than those reported in some previous studies (Whitford and Bryant 1979, Carlson and Whitford 1991, MacMahon et al. 2000), potentially indicating that harvester 


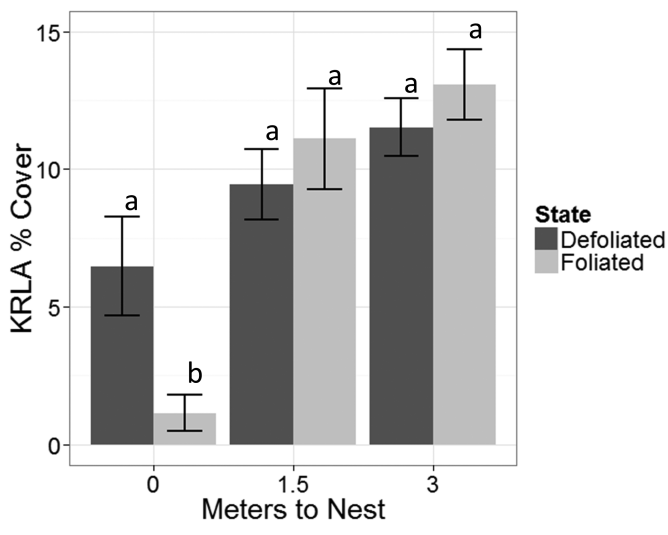

Fig. 2. Mean percent cover $( \pm 1 \mathrm{SE})$ of defoliated and foliated Krascheninnikovia lanata (KRLA) as a function of distance from Owyhee harvester ant (Pogonomyrmex salinus) nests in the shrubland habitat. Different letters denote a significant difference in cover within distance class based on $95 \%$ confidence intervals.

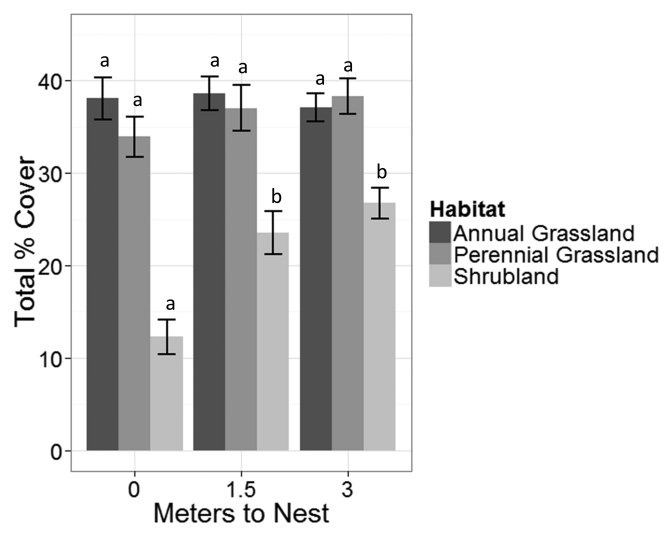

Fig. 3. Total percent cover $( \pm 1 \mathrm{SE})$ of vegetation as a function of distance from Owyhee harvester ant (Pogonomyrmex salinus) nests by habitat. Different letters denote a significant difference in cover across distance classes based on $95 \%$ confidence intervals.

ants are capable of having much greater impacts on vegetation in other regions. Additionally, harvester ants appeared to influence vegetation communities through selective plant clearing, and perhaps seed selection, that depends on species. This is consistent with other studies that have observed harvester ants differentially influencing plant species (Whitford 1988, Carlson and Whitford 1991, Brown et al. 2012). Overall, our work informs the understanding of harvester ant- vegetation relationships in a general sense, as well as within sagebrush-steppe ecosystems.

The effects of harvester ants on plant composition depended on distance-from-nest and plant species. In particular, the effect of ants on specific plant species may be a result of both the nutritional value and the density of these plants near ant nests. Past studies indicate that $B$. tectorum seeds have a relatively high percentage of indigestible cell walls (Crist and MacMahon 1992) and relatively low calorie content per seed (Kelrick et al. 1986) compared to seeds from native grasses, forbs, and shrubs. Further, the long awns of B. tectorum seeds might impede transport or processing of the seeds (Kelrick et al. 1986, Crist and MacMahon 1992). These attributes of B. tectorum seeds could explain why harvester ants often collect them at disproportionately low rates and discard collected seeds in refuse piles where germination is unlikely (Kelrick et al. 1986, Crist and MacMahon 1992, Ostoja et al. 2013). In the annual grassland, B. tectorum was relatively dominant and densely distributed, and there was a significant increase in $B$. tectorum cover with distance from harvester ant nests. This was not so in the shrubland site where B. tectorum cover was relatively low. Dense B. tectorum might decrease soil moisture and sun exposure, and because B. tectorum is not a preferred nutritional resource for harvester ants, it may be advantageous for harvester ants to remove this grass in areas where it is densely distributed and near the nest.

We observed a similar relationship with $K$. lanata density and removal patterns by ants. To our knowledge, there is no literature discussing a trophic relationship between $K$. lanata and harvester ants. However, harvester ants remove leaves from shrubs near their nests, likely to conserve soil moisture (Wight and Nichols 1966) or to increase solar exposure and thus increase foraging periods (Bucy and Breed 2006). In the shrubland, we identified an increase in $K$. lanata cover with distance from harvester ant nests (where K. lanata was relatively dense). We discovered significantly more defoliated than foliated $K$. lanata at the nest edge, but no difference between defoliated and foliated $K$. lanata at the outer distances, suggesting defoliation by harvester ants. Rissing (1988) found that harvester ants (Pogonomyrmex rugosus) disproportionately removed leaves on shrubs that were closer to 
nests and observed up to 300 ants stripping foliage off nearby shrubs. Further, recent restoration experiments on the BOP (our study area) indicated that harvester ants defoliated Wyoming big sagebrush (Artemisia tridentata) seedlings, contributing to a nearly $50 \%$ die-off (M. Germino personal communication). Regardless of the behavioral mechanism, harvester ants modify shrubs and could largely influence the success of shrubland restoration efforts, which is concerning given the threatened status of sagebrush shrublands (Noss et al. 1995, Noss and Peters 1995) and amount of sagebrush seeded or outplanted annually (Arkle et al. 2014).

The behavior of leaf clipping and defoliation of undesirable plants near ant nests likely increases desirable plant species abundance and food availability through competitive release. For instance, $P$. secunda (a native bunchgrass) cover was higher in close proximity to nests at sites where densely distributed and undesirable plants were reduced. The increase in P. secunda cover near nests might result from decreased competition with other plants, or a combination of decreased competition along with increased soil nutrients at the nest edge (e.g., Mandel and Sorenson 1982, Whitford 1988, Wagner et al. 1997, Wilby et al. 2001, Brown et al. 2012). Nowak et al. (1990) observed similar patterns in that Indian ricegrass (Oryzopsis hymenoides, a native perennial bunchgrass) was more abundant near harvester ant nests. They suggested that the most probable mechanism was reduced competition because of selective defoliation and removal of other plant species by harvester ants.

Although ants reduced cover of some individual plant species closer to nests, the percent cover of $S$. altissimum (an introduced forb) or P. juncea (an introduced bunchgrass) was not influenced by distance-from-nest. The relatively large size of S. altissimum and P. juncea may have prevented harvester ants from clipping and removing them, particularly if these plants exhibited substantial growth prior to high ant densities. This explanation, however, seems unlikely as harvester ants are known to influence shrubs (Lei 1999), which are often among the largest plants in desert environments. Perhaps the density of S. altissimum and $P$. juncea was not high enough to initiate a direct removal response by harvester ants, nor an indirect competitive release response trig- gered by ants removing other plant species. In addition, $S$. altissimum seeds are used as a food resource by harvester ants (Schmasow 2015), and thus may be beneficial to have on a site, even if at low densities.

We only detected a significant effect of distance-from-nest on total vegetation cover in the shrubland. This pattern was similar to results from Carlson and Whitford (1991), but inconsistent with other studies where antmediated changes in soil properties (rather than defoliation or clearing) seemed to be the main process influencing plant growth and cover (Whitford 1988, Mull and MacMahon 1997, Brown et al. 2012). The subtle change in total vegetation cover we observed was somewhat contrary to our hypothesis that harvester ants would defoliate densely distributed vegetation. However, the density of vegetation at the grassland habitats may have been low enough that defoliation was unnecessary. Alternatively, selective removal of nonnatives and indirect facilitation of desirable natives near nests, coupled with competitive dominance by nonnatives farther from nests (where less defoliation or clearing occurred), may balance total plant cover across distances. Combining the patterns we observed among species and total vegetation cover provides support for the hypothesis that harvester ants selectively defoliate undesirable plant species and indirectly benefit desirable species. This pattern was observed firsthand in the field with $K$. lanata defoliation, as well as in the data with a near doubling of $P$. secunda cover nearer to nests in annual grassland and shrubland sites. Perhaps defoliation by harvester ants is largely driven by species-specific nutritional decisions, and secondarily driven by a thresholddependent response to vegetation density. This mechanism would be consistent with the patterns we observed at the species and total vegetation level, but additional research is needed to isolate and test these mechanisms. Alternatively, Carlson and Whitford (1991) suggest that the inadvertent dispersal of seeds near disks is possible, and this might also contribute to an increase in the relative abundance of desirable plant species near the nest edge.

\section{CONCLUSION}

Our findings provide insight concerning the extent of ecosystem engineering by harvester 
ants within a sagebrush-steppe ecosystem. However, additional work is needed within different habitats of the Great Basin, as well as other ecosystems, to capture the range of variation in harvester ant engineering, which would help identify general patterns and mechanisms that transcend ecological contexts. This information could directly inform management and restoration activities because the islands of influence associated with harvester ants could contribute to the success or failure of restoration efforts (Byers et al. 2006). Incorporating engineering effects of animals within restoration plans is particularly important to consider when animal activities could limit restoration efficacy through consumption of sown seeds, stripping of shrubs, or modification of resulting plant communities. Indeed, characterizing spatial and temporal patterns, as well as mechanisms associated with ecosystem engineering, advances our understanding of ecosystems, and thus aids conservation and management efforts (Hastings et al. 2007).

\section{ACKNOWLEDGMENTS}

We gratefully acknowledge financial support from the Doris Duke Conservation Scholars Program Collaborative and the U.S. Geological Survey, Idaho Cooperative Research Unit. We sincerely thank M. Modlin for assisting with fieldwork. We thank J. McIver, J. Rachlow, and C. Conway for providing comments that improved this manuscript. This is contribution 1088 of the University of Idaho Forest, Wildlife and Range Experiment Station. Any use of trade names is for descriptive purposes only and does not imply endorsement by the U.S. government.

\section{Literature Cited}

Anderson, K.E., And A.C. Keyel. 2006. Mating flight, metrosis, and semi-claustrality in the seed-harvester ant Pogonomyrmex salinus (Hymenoptera, Formicidae). Insectes Sociaux 53:92-96.

Arkle, R.S., D.S. Pilliod, S.E. Hanser, M.L. Brooks, J.C. Chambers, J.B. Grace, K.C. Knutson, D.A. Pyke, J.L. Welty, and T.A. Wirth. 2014. Quantifying restoration effectiveness using multi-scale habitat models: implications for sage-grouse in the Great Basin. Ecosphere 5:art31. http://dx.doi.org/ 10.1890/ES13-00278.1

Blom, P.E., W.H. Clark, and J.B. Johnson. 1991. Colony density of the seed harvesting ant Pogonomyrmex salinus (Hymenoptera: Formicidae) in seven plant communities on the Idaho National Engineering
Laboratory. Journal of the Idaho Academy of Science 27:28-36.

Booth, D.T., S.E. Cox, and R.D. Berryman. 2006. Point sampling digital imagery with "Samplepoint." Environmental Monitoring and Assessment 123:97-108.

Brown, G., C. Scherber, P. Ramos, and E.K. Ebrahim. 2012. The effects of harvester ant (Messor ebeninus Forel) nests on vegetation and soil properties in a desert dwarf shrub community in north-eastern Arabia. Flora 207:503-511.

BuCY, A.M., AND M.D. BREED. 2006. Thermoregulatory trade-offs result from vegetation removal by a harvester ant. Ecological Entomology 31:423-429.

Byers, J.E., K. Cuddington, C.G. Jones, T.S. Talley, A. Hastings, J.G. Lambrinos, J.A. Crooks, and W.G. WILSON. 2006. Using ecosystem engineers to restore ecological systems. Trends in Ecology and Evolution 21:493-500.

Carlson, S.R., and W.G. Whitford. 1991. Ant mound influence on vegetation and soils in a semiarid mountain ecosystem. American Midland Naturalist 126:125-139.

Cole, A.C., JR. 1932. The relation of the ant, Pogonomyrmex occidentalis Cr., to its habitat. Ohio Journal of Science 32:133-146.

CRIsT, T.O., AND J.A. MACMAHON. 1991. Foraging patterns of Pogonomyrmex occidentalis (Hymenoptera: Formicidae) in a shrub-steppe ecosystem: the roles of temperature, trunk trails, and seed resources. Environmental Entomology 20:265-275.

Crist, T.O., and J.A. MacMahon. 1992. Harvester ant foraging and shrub-steppe seeds: interactions of seed resources and seed use. Ecology 73:1768-1779.

Davidson, A.D., J.K. Detling, and J.H. Brown. 2012. Ecological roles and conservation challenges of social, burrowing, herbivorous mammals in the world's grasslands. Frontiers in Ecology and the Environment 10: 477-486.

Davies, K.W., C.S. Boyd, J.L. Beck, J.D. Bates, T.J. Svejcar, AND M.A. GregG. 2011. Saving the sagebrush sea: an ecosystem conservation plan for big sagebrush plant communities. Biological Conservation 144:2573-2584.

DeFalco, L.A., T.C. EsQue, J.M. Kane, and M.B. NicKLas. 2009. Seed banks in a degraded desert shrubland: influence of soil surface condition and harvester ant activity on seed abundance. Journal of Arid Environments 73:885-893.

Eldridge, D.J., and W.G. Whitford. 2009. Badger (Taxidea taxus) disturbances increase soil heterogeneity in a degraded shrub-steppe ecosystem. Journal of Arid Environments 73:66-73.

Fleming, P.A., H. Anderson, A.S. Prendergast, M.R. BRETZ, L.E. Valentine, and G.E. StJ. HaRdy. 2014. Is the loss of Australian digging mammals contributing to a deterioration in ecosystem function? Mammal Review 44:94-108.

Golley, F.B., And J.B. Gentry. 1964. Bioenergetics of the southern harvester ant, Pogonomyrmex badius. Ecology 45:217-225.

Hastings, A., J.E. Byers, J.A. Crooks, K. Cuddington, C.G. Jones, J.G. Lambrinos, T.S. Talley, and W.G. WILSON. 2007. Ecosystem engineering in space and time. Ecology Letters 10:153-164.

Holbrook, J.D., R.S. Arkle, J.L. Rachlow, K.T. Vierling, AND D.S. Pilliod. 2015. Sampling animal sign in heterogeneous environments: how much is enough? Journal of Arid Environments 119:51-55. 
HowelL, B. 2015. Reclaiming lost territory: the response of Owyhee harvester ants to forager intrusions by neighboring colonies. Boise State University College of Arts and Sciences Presentations: Paper 22.

Jones, C.G., J.L. Gutierrez, J.E. Byers, J.A. Crooks, J.G. Lambrinos, and T.S. TALley. 2010. A framework for understanding physical ecosystem engineering by organisms. Oikos 119:1862-1869.

Jones, C.G., J.H. LaWTON, AND M. SHaCHaK. 1994. Organisms as ecosystem engineers. Oikos 69:373-386.

Jones, C.G., J.H. LaWton, and M. Shachak. 1997. Positive and negative effects of organisms as ecosystem engineers. Ecology 78:1946-1957.

Jorgensen, C.D., and S.D. Porter. 1982. Foraging behavior of Pogonomyrmex owyheei in southeast Idaho. Environmental Entomology 11:381-384.

Kelrick, M.I., J.A. MacMahon, R.R. Parmenter, and D.V. Sisson. 1986. Native seed preferences of shrubsteppe rodents, birds and ants: the relationships of seed attributes and seed use. Oecologia 68:327-337.

Knick, S.T., J.T. Rotenberry, M.A. Schroeder, W.M. Vander Haegen, and C.V. Riper. 2003. Teetering on the edge or too late? Conservation and research issues for avifauna of sagebrush habitats. Condor 105:611-634.

LEI, S.A. 1999. Ecological impacts of Pogonomyrmex on woody vegetation of a Larrea-Ambrosia shrubland. Great Basin Naturalist 59:281-284.

MacMahon, J.A., J.F. Mull, and T.O. CRIst. 2000. Harvester ants (Pogonomyrmex spp.): their community and ecosystem influences. Annual Review of Ecology and Systematics 31:265-291.

Mandel, R.D., And C.J. Sorenson. 1982. The role of the western harvester ant (Pogonomyrmex occidentalis) in soil formation. Soil Science Society of America 46:785-788.

Mull, J.F., AND J.A. MacMahon. 1997. Spatial variation in rates of seed removal by harvester ants (Pogonomyrmex occidentalis) in a shrub-steppe ecosystem. American Midland Naturalist 138:1-13.

Noss, R.F., E.T. LaRoe, AND J.M. ScotT. 1995. Endangered ecosystems of the United States: a preliminary assessment of loss and degradation. USDI National Biological Service Biological Report 28.

Noss, R.F., and R.L. Peters. 1995. Endangered ecosystems: a status report on America's vanishing habitat and wildlife. Defenders of Wildlife, Washington, DC.

NowaK, R.S., C.L. NowaK, T. DeRocher, N. Cole, and M.A. Jones. 1990. Prevalence of Oryzopsis hymenoides near harvester ant mounds: indirect facilitation by ants. Oikos 58:190-198.

Ostoja, S.M., E.W. Schupp, and R. KLinger. 2013. Seed harvesting by a generalist consumer is contextdependent: interactive effects across multiple spatial scales. Oikos 122:563-574.

Ostoja, S.M., E.W. Schupp, And K. Sivy. 2009. Ant assemblages in intact big sagebrush and converted cheatgrass-dominated habitats in Tooele County, Utah. Western North American Naturalist 69:223-234.

Pilliod, D.S., AND R.S. ARKLE. 2013. Performance of quantitative vegetation sampling methods across gradients of cover in Great Basin plant communities. Rangeland Ecology and Management 66:634-647.

R Core Team. 2014. R: a language and environment for statistical computing. R Foundation for Statistical Computing, Vienna, Austria; [accessed 28 August 2014].

Rissing, S.W. 1988. Seed-harvester ant association with shrubs: competition for water in the Mohave Desert? Ecology 69:809-813.

Rust, R.W. 1988. Nuptial flights and mating behavior in the harvester ant, Pogonomyrmex salinus Olsen (Hymenoptera: Formicidae). Journal of the Kansas Entomological Society 61:492-494.

Schmasow, M.S. 2015. Diet selection by the Owyhee harvester ant (Pogonomyrmex salinus) in southwestern Idaho. Boise State University Theses and Dissertations: Paper 891.

Schroeder, M.A., C.L. Aldridge, A.D. Apa, J.R. Bohne, C.E. Braun, S.D. Bunnell, J.W. Connelly, P.A. Deibert, S.C. Gardner, M.A. Hilliard, et al. 2004. Distribution of sage-grouse in North America. Condor 106:363-376.

Suazo, A.A., D.J. Craig, C.H. Vanier, and S.R. Abella. 2013. Seed removal patterns in burned and unburned desert habitats: implications for ecological restoration. Journal of Arid Environments 88:165-174.

Wagner, D., M. Brown, And D. Gordon. 1997. Harvester ant nests, soil biota and soil chemistry. Oecologia 112:232-236

WAGNER, D., AND J.B. Jones. 2006. The impact of harvester ants on decomposition, $\mathrm{N}$ mineralization, litter quality, and the availability of $\mathrm{N}$ to plants in the Mojave Desert. Soil Biology and Biochemistry 38:2593-2601.

Whicker, A.D., AND J.K. DetLing. 1988. Ecological consequences of prairie dog disturbances. BioScience 38:778-785.

Whitford, W., and R. DiMarco. 1995. Variability in soils and vegetation associated with harvester ant (Pogonomyrmex rugosus) nests on a Chihuahuan Desert watershed. Biology and Fertility of Soils 20: 169-173.

Whitford, W.G. 1988. Effects of harvester ant (Pogonomyrmex rugosus) nests on soils and a spring annual, Erodium texanum. Southwestern Naturalist 33:482485.

Whitford, W.G., and M. BRyant. 1979. Behavior of a predator and its prey: the horned lizard (Phrynosoma cornutum) and harvester ants (Pogonomyrmex spp.). Ecology 60:686-694.

WhitFoRD, W.G., AND F.R. KAY. 1999. Biopedturbation by mammals in deserts: a review. Journal of Arid Environments 41:203-230.

Wight, J.R., AND J.T. NichOLS. 1966. Effects of harvester ants on production of a saltbush community. Journal of Range Management 19:68-71.

Wilby, A., M. Shachak, and B. Boeken. 2001. Integration of ecosystem engineering and trophic effects of herbivores. Oikos 92:436-444.

Received 8 May 2015

Accepted 1 December 2015 